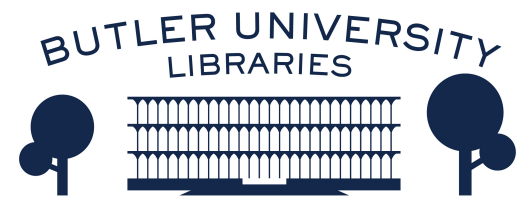

Journal of Hindu-Christian Studies

Volume 32 Discussion of Nathaniel Roberts, To

Be Cared For: The Power of Conversion and

Foreignness of Belonging to An Indian Slum.

Article 2

2019

\title{
Review of Nathaniel Roberts' To Be Cared For:The Power of Conversion and the Foreignness of Belonging in an Indian Slum
}

Eliza F. Kent

Skidmore College

Follow this and additional works at: https://digitalcommons.butler.edu/jhcs

Part of the History of Religions of Eastern Origins Commons

\section{Recommended Citation}

Kent, Eliza F. (2019) "Review of Nathaniel Roberts' To Be Cared For:The Power of Conversion and the Foreignness of Belonging in an Indian Slum," Journal of Hindu-Christian Studies: Vol. 32, Article 2.

Available at: https://doi.org/10.7825/2164-6279.1728

The Journal of Hindu-Christian Studies is a publication of the Society for Hindu-Christian Studies. The digital version is made available by Digital Commons @ Butler University. For questions about the Journal or the Society, please contact cbauman@butler.edu. For more information about Digital Commons @ Butler University, please contact digitalscholarship@butler.edu. 


\title{
Review of Nathaniel Roberts' To Be Cared For: The Power of Conversion and the Foreignness of Belonging in an Indian Slum
}

\author{
Eliza F. Kent
}

Abstract: This article focuses on Roberts' argument that the religiosity of urban Tamil Dalits, or "slum religion," transcends Hindu or Christian affiliation. Roberts' ethnography challenges the dominant discourse surrounding Pentecostal Christianity which asserts that conversion is inevitably divisive, splitting families and communities and even individuals in harmful ways that justify its tight legal regulation. To the contrary, Roberts' fieldwork reveals how the deeply pragmatic nature of Dalit religion allows for significant individual variation and dynamism without inordinate contentiousness. To Be Cared For also contributes to scholarship on women and religion in India, sensitively illustrating the tensions and strains within urban Dalit women's lives that the collective ritual forms of Pentecostal Christianity help to assuage.

BASED on months of intensive, immersive of fieldwork, Nathaniel Roberts' To Be Cared For offers a valuable contribution to the anthropology of religion, and specifically of Hindu-Christian encounter. During his fieldwork, Roberts lived in the pseudonymous Anbu Nagar ("Love Ville"), one among a conglomeration of slums in northern Chennai, which he calls Kashtapattinam ("Trouble Town"). Like Nancy Martin and others who have focused on the religiosity of Indian Dalits, Roberts argues that slum religion has significant features that transcend Hindu or Christian affiliation (Martin 2013). Among these are a profound ethic of care that, against the dehumanizing pressures of economic hardship and caste-based discrimination, has the capacity to turn this little corner of Trouble Town into Anbu Nagar, Love Ville. It is well-known that Dalits have been treated for centuries as non-Hindus, outside the fold, and that as such they have been categorically denied access to the wellsprings of material and spiritual thriving -- from educational and employment opportunities and property

Eliza F. Kent is Professor of Religion at Skidmore College. She received a B.A. from Williams College and an M.A. and Ph.D. from the University of Chicago Divinity School. A scholar of religion in South Asia, she is the author of Converting Women: Gender and Protestant Christianity in Colonial South India (Oxford University Press, 2004), Sacred Groves, Local Gods: Religion and Environmentalism in South India (Oxford University Press, 2013) and articles in venues such as the Journal of the American Academy of Religion, Arts \& Humanities in Higher Education, the Journal for Hindu-Christian Studies, Worldviews: Global Religions, Culture and Ecology, and the Journal for the Study of Religion, Nature and Culture. With Tazim Kassam, she co-edited the volume Lines in Water: Religious Boundaries in South Asia (Syracuse University Press, 2013). Whether engaged with gender or ecology, her research focuses on religious pluralism and its side effects, such as conversion, syncretism, crypto-conversion, reform and revival. 
ownership to temple entry and ritual honors (Mosse 2012; Viswanath 2014). And, as Roberts illuminates in a searing description of the dangers of dehydration, caste Hindus have often operationalized their dehumanization of Dalits by denying them access to the actual wellsprings of water, a form of cruelty with dire symbolic and somatic consequences. In light of this, it is perhaps not surprising that deeply empathetic anthropological fieldwork, which remains simply open to what people do and say without a pre-established commitment to particular etic frameworks, would discover that lived Dalit religion would manifest so differently from lived Hindu religion. What is surprising is the depth and number of established scholarly verities that this approach leads Roberts to question. Roberts challenges dominant scholarly representations of Indian religiosity that generalize elite or Brahmanical discourse to all Hindus, exposing how little traction Brahmanical beliefs about karma, caste, pollution and the afterlife have within Dalit religious discourse. Another feature of dominant scholarly and popular views of religion in India is that differences in belief are at the root of conflict between groups. That too comes into question as Roberts reveals how the deeply pragmatic nature of Dalit religion allows for individual variation and dynamism without inordinate contentiousness. In what follows, I first outline the principal features of Dalit religiosity described by Roberts, connecting these to his intervention into the debate over India's anti-conversion laws, varying forms of which have been passed in nine Indian states. Then I turn to Roberts' analysis of the religiosity of women in the slum, through which he builds on and deepens recent work on Indian Christian women's religiosity.
Roberts argues that among the features that distinguish slum religion are its production of a distinctive variety of universal morality that affirms the humanity of all people. Against a background in which Dalits are considered "outsiders" excluded from mainstream Hindu society and their churches accused of foreign funding, Dalits themselves project a view of moral community that encompasses everyone: everyone belongs, even the so-called foreigner. From the perspective of this moral universalism, caste is condemned as a deeply immoral, unjust social system that is ultimately false - a "lie." When the people of Anbu Nagar discuss caste, which they rarely do in explicit terms, they assert that the division of the human community into an immutable hierarchy has less to do with Hindu theological justifications such as the discourse of purity and pollution and more to do with the naked greed and false pride (perumai) of socially dominant upper castes. Our shared humanity should be sufficient reason for us to care for one another, Roberts' informants assert. And yet, they say, the rich don't do this, particularly not the Indian rich, though they are more optimistic about the generosity of foreigners. The residents of Anbu Nagar locate the basis of economic stratification directly in morality: the meanspirited hoarding of the rich leads them to accumulate wealth, just as the caring generosity of the poor leads them to remain poor. As Roberts summarizes the economic consequences of this ethos of care, "Anyone who cared about others...could never become wealthy as long as there were people in need." (p. 69) This understanding of our common humanity, and our duty to care for one another was shared among Hindus and nonHindus in Anbu Nagar, with apparently no variation across religious affiliation. 
Another shared feature of slum religion is its overwhelmingly practical orientation. Writing of the preponderance of worldly concerns in people's relationships with divine beings - whether Christian or Hindu gods, Roberts asserts,

To say that slum residents considered worldly interests as valid as otherworldly ones, however, risks implying that otherworldly goals had more of a place in slum religion than they did. In reality neither version of slum religion (Christian or Hindu) posited any state of existence an afterlife, ecstatic union with the divine, perception of a higher truth beyond the illusion of phenomenal existence, and so on - in relation to which the concerns of cares of this world might be weighed. ( $p$ 166)

Instead, slum dwellers conceive of religion largely in terms of the individual's relationship with a divine being. Gods were generous, benevolent beings who cared about people. But, they were also demanding, so devotees had to worship gods in order to please them and to behave in ways that avoided sinful, harmful behavior. of paramount importance is finding gods who actually are real and efficacious, and allying oneself with them in order to obtain worldly blessings and support. All slum residents are involved in this pursuit, and understand the underlying material deprivation, health concerns and relationship stress that drive transferring one's loyalties from one god to another. In this context, apostasy is not regarded by slum dwellers as a "crisis," but is understood pragmatically as a necessary shift in course when one's devotion failed to obtain results (178). Even when Christian pastors lament a former congregants' "backsliding," it is out of pity for the harm that would inevitably befall them because Hindu gods simply do not exist, they feel, and therefore devotion to them is futile and foolish. For their part, Hindus sometimes mock the weakness and inefficacy of the Christian God, Jesus, though their theology affirms the ultimate unity of all gods in God; what matters was which aspect of god one turns to, and finds efficacious. Surprisingly, talk like this which calls into question the legitimacy of other people gods, does not degenerate into discord or ill will, as one might imagine. It is, Roberts argues, a side effect of the deeply pragmatic logic and theological realism of slum religion shared by all.

One of the repercussions of these two central features of slum religion - its pragmatic orientation and its embeddedness in moral universalism - is that changing one's religion does not provoke acrimonious splits in the community. Conversion - particularly embracing pentecostal Christianity - requires changes to behavior (such as not smoking or swearing), and alters the array of measures one may employ to deal with supernatural threats such as the evil eye and sorcery (since pentecostal affiliation meant abandoning all such measures and having "faith in Jesus only"). But, according to Roberts, slum dwellers do not try to control each other's religious choices. Contrary to the outcry of Hindu nationalists and secular journalists that conversion inevitably harms an individual's "inner self" or the internal coherence of a community, residents of Anbu Nagar see no such danger in religious conversion. In other words, the divisive harm of religious conversion on individuals and communities which has long been trumpeted by Hindu nationalists, and taken up in Indian newspapers by secular liberals, simply are not to be found in Anbu Nagar. This is an important intervention because, from the colonial period to the present day, one finds a 
pervasive assumption among jurists, politicians and scholars alike that conversion and social division, and therefore conflict, are inevitably intertwined.

Another important contribution Roberts makes to scholarship on south Indian religion is his careful investigation of women's religiosity in the slum, particular among Pentecostal Christians. Here, Roberts provides a sensitive illustration of the tensions and strains within women's lives that the collective ritual forms of Pentecostal Christianity help to assuage. This is accomplished in two chapters that bookend the work, the first describing the economic strategies that very poor families use to keep body and soul together and the other describing how Pentecostal prayer circles help to mend the painful divisions that these economic strategies create among women. In a context in which women are entirely dependent upon the wages of their menfolk and yet are held responsible for the financial management of the household by the discourse of wifely auspiciousness, women's informal loans to one another have emerged as a crucial survival strategy. Such loaning networks have been celebrated within economic development literature as an example of women's ability to pool resources and acquire capital under straightened circumstances. However, Roberts shows us that they also entail shockingly usurious practices. Through his painstaking unpacking of the rules that govern how women decide who gets loaned how much money and under what conditions, we see that the networks of women bound together in relations of indebtedness benefit some, but also monetize relationships with kin and neighbors in a way that can lead to significant harm. Both creditworthiness, and its shameful opposite, inability to pay, were powerful indicators of one's status within the moral community of the slum. This situation was intensified by the fact that one could only avoid one's debtors (who were also friends, neighbors and family) by going into hiding, effectively withdrawing from the moral community in disgrace. For these reasons, indebtedness was one of the two leading causes of women's suicide. Extreme marital discord was another, and it doesn't take an anthropologist to deduce that the two were closely related - as indebtedness could greatly exacerbate conflict between spouses, and vice versa.

Roberts' analysis of these complex and often treacherous lending networks among women helps explain the attractiveness of Pentecostalism to slum women, which he explores in chapter six. He does not deny the patriarchal bias of pentecostal Christianity, but illuminates its complexly gendered power dynamics, and thereby adds to a rich body of scholarship, beginning with the pioneering work of Elizabeth Brusco and Bernice Martin in Columbia, that demonstrates how women make the most of opportunities for leadership and agency within pentecostal and charismatic Christianity (Brusco 1995 ; Martin 2003). As Roberts points out, pentecostal Christianity in the slum is organized around the extraordinary charisma of pastors. Each of the dozen or more pentecostal churches in Kashtapattinam (trouble town) has two names. The formal official name painted on a signboard outside the church is something like, "Apostolic Liberation Divine Assembly," or "Loving Prayer House," but residents of the slum rarely use those names. Rather, they refer to "Samuel's church," or "Yesudasan's church," or sometimes just "Samuel" or "Yesudasan." This identification of the church with its male pastor was fitting because, "a slum church was not only the pastor's personal property, but his life's work - the 
worldly manifestation of his God-given spirit powers and in many ways an extension of himself" (p. 186). These independent Pentecostal pastors work tirelessly to attract parishioners (most often from one another's "flocks," or from those of Church of South India or Roman Catholic churches) and to resource the simple thatch and pole structures that constituted the physical church with ceiling fans and cordless microphones. An influential narrative in contemporary India portrays Pentecostal churches as lavishly supported by American Christian donors, thus reinforcing the sense that present day Indian Christians are somehow alien within or traitors to the Indian nation, which is increasingly identified as Hindu in the mode of Modi-era conservative modern brahmanical Hinduism. This narrative fuels a steady stream of daily acts of violence against Indian Pentecostals, as Chad Bauman has documented (2015). But what his and Roberts' research reveals is that the vast majority of these independent pentecostal churches are self-funded; indeed, they operate at a bare bones level that does not require much in the way of material investment. It is the pastor's capacity to serve as a channel for divine favor that allows for the flourishing of a church, whether measured by the number of congregants, healing miracles, or the degree to which it was resourced with things like ceiling fans and cordless microphones.

But, in conversation with Max Weber's famous theory of charisma, which locates charisma in an individual's qualities (considered by the faithful as "gifts from God"), Roberts argues that in fact the pastor's charisma is produced by the women in the congregation whose weekly performances of ecstatic devotion, and day to day loyalty, provide evidence of his supposed power. Each male pastor is thus supported in his work by a cadre of dedicated female congregants. They do many different things for the church, including using the microphone to broadcast the troubles that afflict their households and themselves thereby directing some moral disciplining toward wayward husbands and lackadaisical sons. Another way in which the cadre of female congregants supports the gradual moral transformation of the slum community is through their weekly prayer circles. Every Sunday, the charismatic pastor gives his high wattage performance of preaching and healing, but the implicitly agreed upon index of the preacher's power as a conduit for God's Presence is actually the women's shouts of allelulia, their coming forward to be healed, and their ecstatic swaying and swooning. Morover, cadres of dedicated lay women provide crucial support for each male pastor and the church community during the week. At this time women go out in prayer teams and systematically visit all the households in the congregation, and others - Hindu or Christian - that invite them to come pray. In the process of regularly talking to women about their lives, and praying over their problems, and asking them to pray for women suffering perhaps even more than they are, they assuage the silent, isolated suffering of those who may be alienated from each other because of the usurious practices of the lending networks described earlier. They not only help to assuage that pain, and help women feel supported and affirmed, but they also create a new moral community whose core ethos is that Christians should actively take on the sufferings of others, as Christ took on the woe of the world.

Roberts' beautifully written and elegantly organized book delivers ground-breaking insights into the nature of lived religion among some of India's poorest and most 
8 Eliza F. Kent

socially marginalized citizens. It is not uncommon for historians and ethnographers in the subfield of Hindu-Christian studies to describe the blurry, frequently effaced boundary between Hindu and Christian, but rarely is this done in such a sustained way based on rigorous immersive ethnography. To Be Cared For will be an excellent addition to courses on the anthropology of religion, on global pentecostal and charismatic Christianity, and on contemporary lived religion, whether in India or globally.

\section{Works Cited}

Bauman, Chad M. 2015. Pentecostals, Proselytization and Anti-Christian Violence in India. New York: Oxford University Press. https://doi.org/10.1093/acprof:oso/9780 190202095.001 .0001

Brusco, Elizabeth E. 1995. The Reformation of Machismo: Evangelical Conversion and Gender in Columbia. Austin: University of Texas.
Martin, Bernice. 2007. "Pentecostal Gender Paradox: A Cautionary Tale for the Sociology of Religion," pp. 52-66, in Richard K. Fenn, eds., The Blackwell Companion to Sociology of Religion. New Jersey: Blackwell Publishing. https://doi.org/10.1002/9780470998571. ch3

Martin, Nancy M. 2013. "Fluid Boundaries and the Assertion of Difference in Low-Caste Religious Identity," pp. 239-269, in Eliza F. Kent and Tazim Kassam, eds, Lines in Water: Religious Boundaries in South Asia. Syracuse, N.Y.: Syracuse University Press.

Mosse, David. 2012. The Saint in the Banyan Tree: Christianity and Caste Society in India. Berkeley: University of California Press. https://doi.org/10.1525/california /9780520253162.001.0001

Viswanath, Rupa. 2014. The Pariah Problem: Caste, Religion and the Social in Modern India. New York: Columbia University Press. https://doi.org/10.7312/visw16306 